\title{
A Study on Consumer Buying Behavior towards Wai Wai Noodles in Kathmandu Valley
}

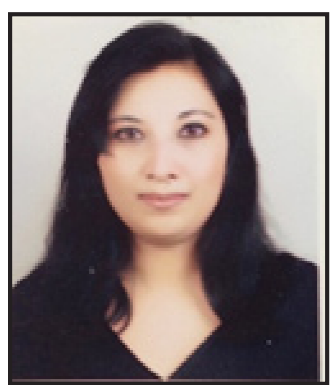

Mikha Shrestha, MPhil*

\begin{abstract}
This research overviews buying behaviors and their relations to the levels of consumer satisfaction. While approaching consuming behavior, the researcher studies not only the act of purchase, but also the pre-purchase stage and post-purchase one. Only the whole study of buying behaviors gives a possibility to determine the relationship between buying behaviors and consumer satisfaction. This paper is aimed to showing that, while buying behaviors can be pre-determined to some extent, it is hard to manipulate them in order to increase satisfaction. In order to ensure customer satisfaction with products and services it is essential to study customer behaviors in a particular market and adjust the product according to them. The study focuses on the consumer's buying behavior towards, 'brand' Wai Wai instant noodle in Kathmandu Valley and the reason behind its popularity, than other noodle across the consumers. Fast foods are the foods that can be prepared quickly and junk foods are the preprepared or packaged food. These foods do not take much time to cook and are also tasty, so they are quite popular among the people of every age group. The market of the junk foods is growing every year. There are a number of junk food production companies in the market and they are growing in size with the growing popularity of the junk foods. The noodles companies are producing noodles in large variety and taste so that the consumers of the noodles never get bored by the same taste every time. This has led to the increase of the noodles market globally. The market of Nepalese noodles companies have not only been limited within the country's boundary but also it has been exporting its products to various countries. It still has the potential and scope to expand more.
\end{abstract}

Keywords: Consumer buying behavior, Satisfaction, Brand, Marketing.

\section{Introduction}

Nepalese noodles industry started in the 1980's with the establishment of Gandaki Noodles. There are many noodles companies in Nepal today as the noodles have been extremely popular in Nepal. Wai Wai is the first brown noodles brand that was produced in Nepal. Rara was the first noodles brand in Nepal but it was white noodles. Wai Wai was produced by Chaudhary group. It was established in 1984 in Kathmandu in technical collaboration with Thai Preserved Food Factory, Thailand. It is a brown noodle which can be consumed raw without cooking it as it is already baked more and cooked while producing it. It became

* Lecturer, Shanker Dev Campus, Tribhuvan University, Nepal 
an instant hit in Nepalese market because the taste was new to most of the consumers in the market. Only a fragment of the customers in the market had tasted brown noodles before. But, Wai Wai soon became a popular brand because its taste was preferred by the consumers in the market. Wai Wai then became dominant in the Nepalese noodles market for a long time. Noodles and Wai Wai became synonym to each other in Nepal until the introduction of another instant noodles brand 'Mayos' in the year 2001. Until the introduction of Mayos in the domestic noodles market, many noodles brand entered and exited unable to compete with Wai Wai. Wai Wai, today, face competition in the domestic market from various competitors, but it still remains one of the dominant noodles brand in Nepal

(www.info@noodleindustry.org).

This research paper is a study on the the Nepalese noodles industry and the consumer buying behavior. This study aims to provide the information on the consumer buying behavior towards Wai Wai noodles in Kathmandu Valley.

This study attempts to answer the following research questions:

- How much conscious are consumers regarding the brand?

- What is the consumers' level of satisfaction with Wai Wai?

- What is the consumer's feedback on Wai Wai?

The study aims to achieve the following research objectives:

- To find how much conscious are consumers regarding the brand?

- To assess the consumers' level of satisfaction with Wai Wai.

- To analyze the consumer's feedback on Wai Wai.

\section{Literature Review}

Consumer Behavior reflects the totality of consumer's decisions with respect to the acquisition, consumption and disposition off goods, services, time and ideas by (human) decision making units. Buyer Behavior particularly is the study of decision making units as they can buy for themselves or others. Thus, buying behavior particularly involves collective response of buyers for selecting, evaluating, and deciding and post purchase behavior. Buyer behavior is the study of human response to services and the marketing of products and services (Krishna; 2006:50-53).

Rai (2014) had written an article on "Impact of Advertising on Consumer Behaviors and Attitude". He reported that, in the current era of information explosion and the world of media, advertisement plays a major role in changing the behavior and attitude of consumer towards the product shown in the advertisement. The advertisements not only change the way of product consumed by user but alter the attitude with which they look at the product. 
Thangasamy \& Patikar (2015) had written an article on "Factors Influencing Consumer Buying Behavior". Both of them disclose that Consumer decision making varies with the type of buying decision. Comparatively, complex and expensive purchases, like durable procurements, are likely to involve more buyer deliberations and more participants. The degree of differences and preferences among brands is highly determined by the degree of buyers' involvement in decision making.

Khaniwale (2016) had studied on the topic "Consumer Behavior". She stated that consumer behavior is very important in the marketing field as it forms the basis of marketing strategies. The study of consumer buying behavior facilitates to comprehend the concern such as what the buyers think, what their feelings are, what the reasons behind their decision are, and how they pick among several options.

Koirala (2017) had published an article on "Marketing Decisions". He highlighted that sales promotion refers to the activities of a non-recurrent nature which is used to reinforce personal selling and advertising for stimulating consumer purchasing and dealer effectiveness. He further stated that it is a consumer perception that often retaliates against a competitor's sales promotion.

Noman (2018) had published an article "Impact of Brand Image and Advertisement on Consumer Buying Behavior". He stated that, brand image and advertisement play a crucial role to boost up any business performance as brand image is an implied tool which can positively change people's buying behavior and advertisement is behaving as a driving force for any business as it is an effective source to convey message and stay in customer's minds.

\section{Research Gap}

Definitely, the above studies have shed light on the consumer buying behavior and consumption pattern of Wai Wai noodles. However, all of the above researchers are confined to influencing factor of consumers buying behavior and also focus on their design, brand, and quality. Therefore, this study attempts to diagnose the core aspect of consumer buying behavior towards Wai Wai noodle. It attempts to show the independency between age of consumers and brand consciousness on behalf of the latest opinion survey. The previous studies have probably not researched in Wai Wai buying behavior in Kathmandu valley. So, this study has been focused on studying buyer behavior and their influencing factor of Wai Wai instant noodle in Kathmandu valley.

\section{Methodology}

There was an extensive use of primary information in this research rather than the secondary information. This study mainly aims to find out trends of noodle consumption and factors influencing buyer's behavior of the Nepalese market and all the Kathmandu residence ultimate consumers of the products selected for the study are considered as the population of the study. The population of Kathmandu city is 1,442,271 in 2018 (www.cbs.gov.org). Out of 
this huge population, a sample of 100 consumers is taken for the study. The consumers thus selected as sample for the study have been picked up on convenience sampling basis taking into consideration that various age groups with proper differentiation on variables such as age, sex, literacy, family system, income level etc. are included.

\section{Data Analysis}

In this section, an attempt has been made to assess the consumer buying behavior towards Wai Wai noodles in Kathmandu Valley. The analysis has been done on the basis of responses made by the respondents. In course of conducting this research, 100 consumers are selected as respondents and attempted to find out their views and opinions.

\section{Consciousness about the Brand}

During the survey, the conscious about the brand and branded product is asked.

Table 1: Brand Consciousness for Noodle

\begin{tabular}{|c|c|c|c|c|c|c|}
\hline \multirow{2}{*}{ S.N } & \multirow{2}{*}{ Ages } & \multicolumn{5}{|l|}{ Frequency } \\
\hline & & Conscious & $\%$ & Not conscious & $\%$ & Total \\
\hline 1. & Under 15 Yrs & 11 & 11 & 14 & 14 & \multirow{5}{*}{100} \\
\hline 2. & (15-25) Yrs & 17 & 17 & 8 & 8 & \\
\hline 3. & (25-35) Yrs & 20 & 20 & 5 & 5 & \\
\hline 4. & Above 35 & 18 & 18 & 7 & 7 & \\
\hline & Total & 66 & $66 \%$ & 34 & $34 \%$ & \\
\hline
\end{tabular}

(Source: Opinion survey 2018)

During the survey, it is found that $66 \%$ are conscious about brand and $34 \%$ are not conscious, about the brand.

\section{Consumers Satisfaction with Wai Wai}

Table 2: Consumers Satisfaction with Wai Wai

\begin{tabular}{|c|c|c|c|}
\hline S.N & Satisfaction & Frequency & Percentage (\%) \\
\hline 1 & Yes satisfied & 76 & 76 \\
\hline 2 & Not satisfied & 24 & 24 \\
\hline & Total & $\mathbf{1 0 0}$ & $\mathbf{1 0 0}$ \\
\hline
\end{tabular}

(Source: Opinion survey 2018)

Regarding level of satisfaction and dissatisfaction, $76 \%$ are found to be satisfied and $24 \%$ of them are not satisfied. 


\section{Consumer's Feedback on Wai Wai}

Some of the major advices given by consumers during the surveys are listed below.

Table 3: Consumer's Feedback For Wai Wai

\begin{tabular}{|l|l|c|c|c|}
\hline S.N & $\begin{array}{l}\text { Consumer's Advice and wishes Towards } \\
\text { Wai Wai Noodle }\end{array}$ & Code & Frequency & $\begin{array}{l}\text { Percentage } \\
\text { (\%) }\end{array}$ \\
\hline 1. & Sufficient nutrition should be added & A & 12 & 12 \\
\hline 2. & $\begin{array}{l}\text { More sales scheme and offer should be given } \\
\text { all the time. }\end{array}$ & B & 13 & 13 \\
\hline 3. & $\begin{array}{l}\text { Seasonings are less. It would be goods in } \\
\text { several seasonings. }\end{array}$ & C & 12 & 12 \\
\hline 4. & Regular customer card should make. & D & 1 & 1 \\
\hline 5. & Quality and price both should be upgrade. & E & 11 & 11 \\
\hline 6. & Price should not be high. & F & 9 & 9 \\
\hline 7. & $\begin{array}{l}\text { It would be better if it could be found in } \\
\text { 100gms packet. }\end{array}$ & G & 7 & 7 \\
\hline 8. & To reduce Price. & H & 23 & 23 \\
\hline 9. & To put playing kits inside packet & I & 10 & 10 \\
\hline 10. & Buy three get one free & J & 2 & 2 \\
\hline & Total & $\mathbf{1 0 0}$ & $\mathbf{1 0 0}$ \\
\hline
\end{tabular}

(Source: Opinion survey 2018)

During the survey, many consumers responded accordingly what they wished about Wai Wai. $23 \%$ of respondent responded to decrease price, $12 \%$ suggested to increase nutritional value, $13 \%$ offered to promote sales scheme, $12 \%$ suggested on seasonings related comments, $11 \%$ of respondent focused on the price and quality of noodle, $10 \%$ asked to put playing kids inside packet, $7 \%$ people wished to increase noodle size and so on.

\section{Major Findings of the Study}

- Majority of people are conscious about the brand. $66 \%$ consumers are conscious about the brand. $34 \%$ of the consumers are not conscious about the brand.

- $\quad$ People are satisfied with Wai Wai noodle.

- Majority of consumer provided feedbacks like sales scheme should be increased, addition of nutrition level, consistent price, playing accessories inside packets.

\section{Conclusion}

From the above findings it is clear that Wai Wai is well-known brand and has strong brand consciousness in the minds of Nepalese consumers. The consumers have relatively high consciousness to the Wai Wai 'brand' than other branded noodles. Attitudes of consumers is 
favorable than for other products. Majority of consumers are satisfied and buy the Wai Wai in the intention of the taste. Moreover, favorable attitude lead to future purchasing intention, hence it creates frequently consumption from loyal consumer and new consumer. It is also concluded that there is dependency between the age group and brand consciousness. Thus, consumers considered that, Wai Wai have been giving its best performance with its best attribute like taste and flavor and has potential to be leading brand in noodle industries.

\section{References}

Khaniwale, M. (2016).Consumer Behavior. USA: International Journal of Innovation and Scientific Research, Volume 14, No. 2, 278-286.

Koirala, K. (2017). Marketing decisions. Kathmandu: Business Journal. M.K Publisher, No. 2.

Krishna, C. N. (2006). Consumer Behavior. New Delhi: Discovery Publishing House.

Loudon, D. L., Bitta, A. (1993). Consumer Behaviour. New York: McGraw- Hill Inc .

Noman, A. (2018).Impact of Brand Image and Advertisement on Consumer Buying Behavior. World Applied Science, IDOSI Publication, Volume 3.

Rai, M. (2014).Impact of Advertising on Consumer Behavior and Attitude. Business Journal, Volume 3, No. 2.

Thangasamy, E., Patikar G. (2015). Factors Influencing Consumer Buying Behaviour. India: Global Journal of Management and Business Research, Volume 14, Issue 5. 